\title{
Body Packers and Imaging: A Case Report
}

\author{
Canlı Kuryeler ve Görüntüleme: Olgu Sunumu
}

\author{
Onur Tutar', (D) Yonca Senem Akdeniz ${ }^{2}$, (D) Türkan İkizceli ${ }^{3}$, (D) İbrahim İkizceli² \\ 1-İstanbul Üniversitesi-Cerrahpaşa, Cerrahpaşa Tıp Fakültesi, Radyoloji Anabilim Dalı. 2-İstanbul Üniversitesi-Cerrahpaşa, Cerrahpașa Tip \\ Fakültesi, Acil Tıp Anabilim Dalı. 3-Sağılı Bilimleri Üniversitesi, Haseki Sağlık Uygulama ve Araştırma Merkezi, Radyoloji Anabilim Dalı.
}

\begin{abstract}
Introduction: The body-packer is an international smuggler who ingests packed illicit drugs. Imaging is very important for diagnosis and management of these patients.

Case report: We present a case of cocaine body-packing detected through scan. A 50-year-old Brazilian male was brought to the emergency department for detailed clinical examination and to verify any possible illicit drug packages within the gastrointestinal system. After the absence of drug intoxication symptoms, we performed abdominal computed tomography scan. And it showed the presence of ingested packets from stomach to rectum. The patient was kept under surveillance and during his observation in hospital he excreted all cocaine packets.

Conclusion: Body packers put themselves at considerable risk as rupture of packet inside the body may be fatal. The patients should be monitored to detect complications, enabling early treatment, and to remove or assist in the expulsion of drug packages from the body. Computed tomography is a fast, reliable and reproducible method for detection of ingested packets.

ÖZET

Giriș: Canlı kurye, paketlenmiş uyușturucuları vücudunda taşıyan uluslararası bir kaçakçı olarak tanımlanmaktadır. Görüntüleme yöntemleri bu hastaların teşhisi ve takibi açısından çok önemlidir.

Olgu Sunumu: Sizlere bilgisayarl tomografi ile teșhis koyduğumuz kokain paketleri taşıyan canlı kurye olgusunu sunmaktayız. 50 yaşında Brezilyalı erkek hasta klinik muayene ve gastrointestinal sistemde olabilecek șüpheli uyuşturucu paketlerinin tespiti amacıyla acil servisimize getirildi. Intoksikasyon bulgularının olmadığı belirlendikten sonra Bilgisayarlı Tomografi görüntülemesi gerçekleştirildi ve mideden rektuma kadar olan çok sayıda kokain paketlerine ait görüntü saptandı. Hasta servisimizde konservatif takip altında tutuldu ve sonucunda tüm paketleri defekasyon ile çıkardı.

Sonuç: Canlı kuryeler, uyușturucu paketinin yırtılmasının sonucu ölümcül olabileceğinden dolayı kendilerini büyük bir risk altına sokmaktadırlar. Bu tür hastalar için olası komplikasyonları saptamak, erken tedavi olanağ să̆lamak ve gerektiğinde yutulmus paketlere cerrahi müdahalede bulunmak amacıla mutlaka görüntüleme yöntemlerine başvurulmalıdır. Bilgisayarlı tomografi vücut içindeki paketlerin saptanmasında hıll ve güvenilir bir radyolojik metottur.
\end{abstract}

Key Words:

Body packer,

Computed tomography,

Illicit drugs,

Imaging.

Anahtar Kelimeler:

Canll kurye,

Bilgisayarll tomografi,

Uyuşturucu,

Görüntüleme.

\section{INTRODUCTION}

The body packer is an international smuggler who ingests packed drugs in order to abduct them abroad (1). This term was described for the first time in 1973 by Deitel and Syed (2). Packages of illicit drugs may be concealed within the body by swallowing or insertion into the vagina or rectum (3). Cocaine, heroin and cannabis products are the most ingested drugs but there are also many kind of illicit drugs being reported (4). According to radiological features; cannabis is radiopaque, cocaine is isodense, and heroin is radiolucent but cocaine and heroin may also be more hypodense than feces (1) Body packers or mules may present to the emergency department with drug toxicity, intestinal obstruction, and bowel perforation or more commonly, requested by law-enforcement officers for medical confirmation or exclusion of suspected body packing (5). Radiological imaging has an important role in detecting body packing in potential drug carriers.
We present a case of cocaine body packing that successfully detected through computed tomography (CT) scan with approximate number of packages and exact localizations in the gastrointestinal tract.

\section{CASE REPORT}

A 50-year-old Brazilian male was arrested by the police, after arriving at Istanbul Ataturk airport from an international flight, under suspicion of narcotic bodypacking. Although he denied any recreational drug use, police identify the suspect from their travel route and destination, doubtful details about journey, local contact person with relevant information and more significantly, some opioid-receptor agonist pills in his pocket. He may had taken these pills in order to increase the time of stay of substances in the intestine and suppress the gastrocolic reflex. The suspect was brought to the emergency department for detailed clinical examination and to verify any possible illicit drug packages within the gastrointestinal system. On clinical presentation, he 


\section{Tutar et al.}

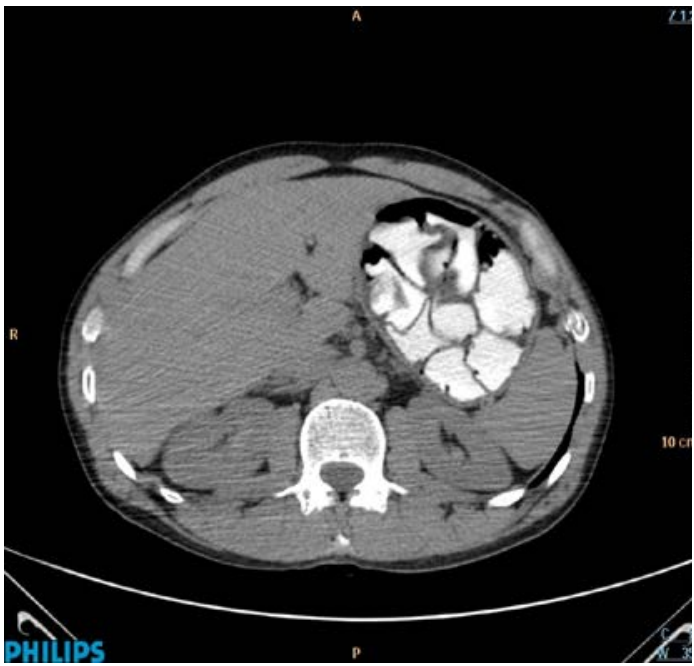

Figure 1: Axial CT scan shows that the lumen of the stomach is full of irregularly shaped hyperdense foreign bodies surrounded with a narrow and sharp hypodense boundary that contains air.

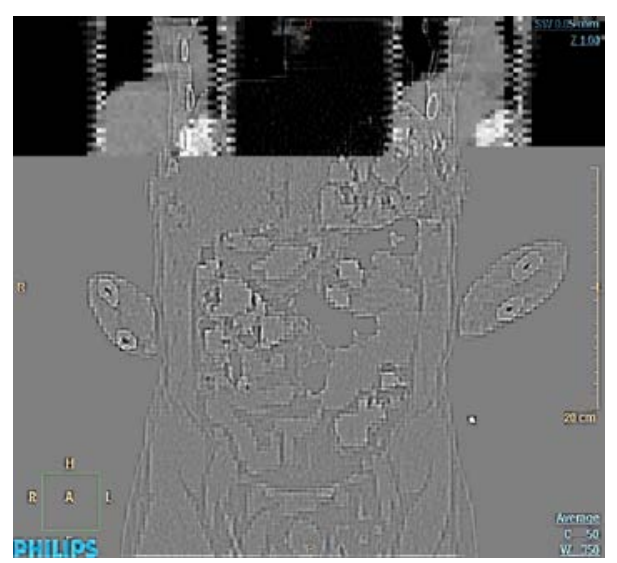

Figure 3: Coronal CT image of the same patient. Hyperdense cocaine packages with the same density as oral contrast are observed mostly in the stomach, ascending colon and intestinal bowel.

appeared well with the exception of mild pain in the epigastrium and slight abdominal distention. His vital signs were: blood pressure 140/70 mm Hg, heart rate 81 beats per minute, respiratory rate 17 breaths per minute, and temperature $37.1^{\circ} \mathrm{C}$. The only significant physical finding was mild epigastric tenderness. Cardiopulmonary, rectal examinations and electrolytes, complete blood count, liver enzymes were all within normal limits. After the absence of drug intoxication symptoms, we decided to perform a non-contrast abdominal CT scan. CT findings showed the presence of more than thirty rounded foreign bodies striking from stomach to rectum (figure 1-4). At the fallowing the patient admitted that he has swallowed packages of cocaine. Stomach was full of with irregular oval shaped hyper-dense packages (figure 1). These ovular hyperdense opacities are surrounded by a thin line of air (figure 1). The density of powder in the packets was measured about 200HU which is similar to oral CT contrast. The additional drug packages were identified

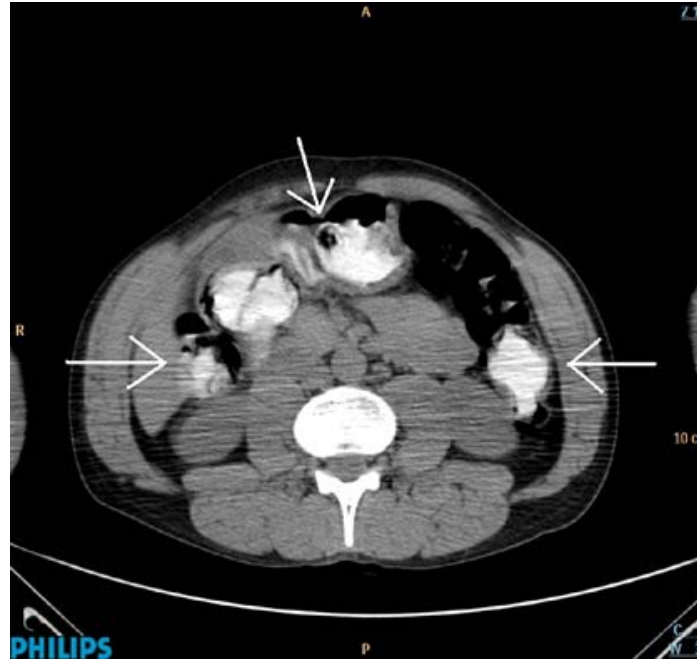

Figure 2: Hyperdense appearance of cocaine packages at gastric antrum (down arrow), ascending colon (right arrow) and descending colon (left arrow).

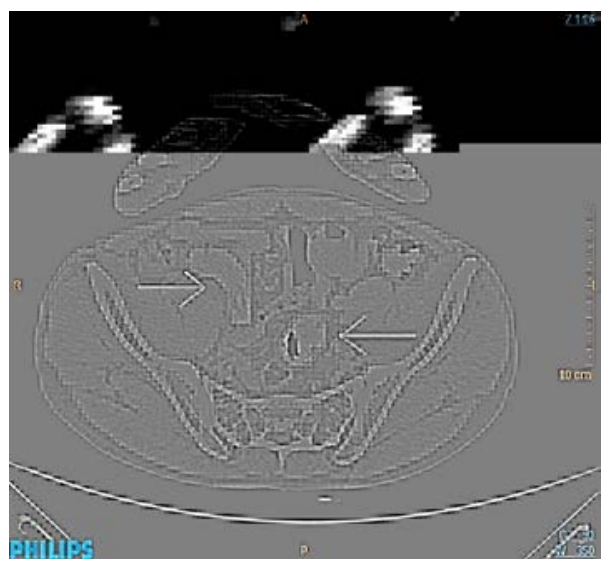

Figure 4: Packages of cocaine are visible in the distal ileum (right arrow) and sigmoid colon (left arrow).

in the colon and distal ileum (figure 2-4). The CT scan showed no radiological signs of intestinal obstruction.

Because of no viable complications, laxatives are administered with caution and the patient is monitored for a period of time. The patient remained asymptomatic and a proton pump inhibitor was administered to reduce the risk of degradation of the bag because of the stomach's acidity. The patient was kept under surveillance and during observation at hospital he excreted 33 packets within 3 days. Then a rapid test confirmed that these bags contained cocaine.

An informed consent was obtained from the patient for the publication of this manuscript.

\section{DISCUSSION}

The general characteristics of body packers are males returning from a trip abroad in a location with a history of illicit drug exporting and history of frequent trips especially from Africa (6). But there are a wide variety of couriers from children to pregnant women (7). They usually carry drugs like cocaine, opium, heroin and 
amphetamines and generally carry about one kilogram of drug, divided into 30 to 70 packets (8). The package may be wrapped in cellophane, layers of latex, rubber cots, condoms, plastic bags, aluminum foil, plastic foil or wax sealing $(9,10)$. There are four types of packet being described, the difference between them are the number of layers, material type and the durability (2). Body packers concealing the drug packets by swallowing use constipating substances such as diphenoxylate or ioperamide during transport and laxatives to accelerate excretion after arrival and also coal tablets for prevent drug absorption against packet rupture risk $(2,11)$.

The packets taken by oral way are round and small and usually about $2 \mathrm{~cm}$ or less (12). The packets inserted through vagina or rectum are usually oval and about 4$6 \mathrm{~cm}$ in length and 2-3 cm in width (12).

Plain abdominal radiography is imperfect as an imaging modality because it is difficult to delineate the margins of the packets and differentiate them from residual bowel contents, especially after enemas and multiple bowel movements but it is steel the first and most chosen modality $(2,11,13)$. It's been reported that radiography has a sensitivity of $77 \%$ to $90 \%$ (14). Low-dose linear slit digital radiography (LSDR) also could be a first choice if available $(2,15)$. LSDR is a whole-body scanner usually used as a security detector as well as a trauma scanner, but its images could be a bit distorted $(2,15)$. Therefore, CT is the best modality for packet detection which have a sensitivity of $95.6 \%$ to $100 \%$ (2). But the effect of contrast is not clear (10). Recent data indicates that non-contrast multi-detector CT without bowel preparation is a fast, reliable and reproducible method for detection of ingested packets $(10,16)$. Plain abdominal radiography is an easy, fast, useful and effective method of diagnosis. But smaller ingested materials by body stuffers can be missed easily and studies also report false-negative results from abdominal x-rays of body packers in radiography (17). Because of this we can use another more sensitive imaging modality. CT is clearly the best method for detecting foreign bodies and the use of helical CT has been widely advocated in the literature for detection, location and density characterization of various non-metallic foreign bodies (1-10).

Ultrasound (USG) has also been used for detection, but it has limited resolution, and will miss a significant number of packets (18). We can see the packets as oval or round smooth-surfaced hyperechogenic shapes and they will show dorsal echo extinction as well $(2,12)$. The positive predictive value of USG was reported as $97.6 \%$ with an accuracy of $94 \%$ (12). Non-contrast Magnetic Resonance Imaging (MRI) also can be used but has some limitations for the lack of protons and bowel motion artefacts, so spasmolytic should be given before imaging $(2,3)$.

There are some special radiological findings for diagnosis. The "double-condom sign" is a crescent shape hyperlucency along the edge of an ovoid opacity
$(2,12)$. The "tic-tac sign is uniformly shaped oblong opacity and the "parallelism sign" is uniform oblong opacities aligning parallel to each other $(2,12)$.

The radiological diagnosis of packets may depend on the number, size, density, position, and air-substance interfaces (17). Non-contrast multi-detector CT has been reported to be more accurate than radiography in the detection of the drug-filled packets because of its improved contrast resolution and the elimination of projections of overlapping structures (19). It has been felt to be sensitive enough to detect packets even if mixing with water, oils, or other liquids has occurred in an attempt to make them less visible $(13,20,21)$. With its high sensitivity and specificity at low radiation exposure, this CT technique might replace conventional radiography as the first-line imaging modality at body packing detection (19). In addition, according to a radiation-based imaging study a single abdominal lowdose CT would be adequate for most of the cases rather than standard doses (4).

Before the examination the physician should explain carefully and in detail potential life risk of this situation to the patient and convince him/her to accept the examination and the treatment (7). The treatment is usually conservative unless there are signs or symptoms of toxicity, bowel obstruction or perforation (3). Proton pump inhibitors and laxatives can be useful. Whole bowel irrigation (WBI) with polyethylene-glycol is a preferable choice $(6,7,22)$. The difficulty of conservative management is to decide the need and the time of intervene (6). Management protocols can be helpful for fallow-up (22). Before discharge control CT is necessary because there might be residual packets. According a study even after two defecations without packet $\% 10$ of body packers showed residual packets and $70 \%$ of these packets were missed on radiography (14). Don't forget that residual packets are not an indication for surgery $(3,8)$.

In case of packet rupture a wide spectrum of toxidromes can occur $(8,17)$. The risk of packet rupture increases with the time of remain in the gastrointestinal tract (13). This life treating setting is called "body packer syndrome', and general sign and symptoms are abdominal pain, vomiting, constipation, loss of consciousness, and seizures (17). Naloxone is the safe and effective antidote for heroin, but the condition may require high doses (7). If surgery is indicated proximal enterotomies are a better choice and multiple enterotomies are not preferable (6).

\section{CONCLUSION}

People are using body-packing for concealment and transit of narcotic materials to avoid of detection by law enforcement agencies as well as retrieval once the target import country is reached. Imaging is very important for diagnosis and management of these patients. A negative plain abdominal radiography does not exclude the diagnosis and an unenhanced CT should be performed 


\section{Tutar et al.}

(2). If we must not give radiation to the patient USG and MRI are also could be used. The patients should be monitored to detect complications, enabling early treatment, and to remove or assist in the expulsion of drug packages from the body (3). While care is taken to ensure safe transit through the gastrointestinal tract without rupture, these measures are not always effective. Swallowers put themselves at considerable risk as rupture of a single packet inside the body may be fatal, depending on the type and concentration of drug being ingested (23).

ÇIKAR ÇATIŞMASI

Tüm yazarlar çıkar çatışması olmadığını beyan eder.

\section{REFERENCES}

1. Shahnazi M, Hassanian-Moghaddam H, Gachkar L, et al. Comparison of abdominal computed tomography with and without oral contrast in diagnosis of body packers and body stuffers, Clinical Toxicology. 2015;53(7):596-603. DOI: 10.3109/15563650.2015.1054501.

2. Pinto A, Reginelli A, Pinto F, Sica G, Scaglione M, Berger FH, et al. Radiological and practical aspects of body packing. Br J Radiol 2014;87: 20130500

3. Glovinski PV, Lauritsen ML, Bay-Nielsen M, et al. Asymptomatic body packers should be treated conservatively. Dan Med J 2013;60(11):13.

4. Schulz B, Grossbach A, Gruber-Rouh T, et al. Body packers on your examination table: How helpful are plain x-ray images? A definitive low-dose CT protocol as a diagnosis tool for body packers. Clinical Radiology. 2014;69:e525-e530.

5. Bulstrode N, Banks F, Shrotria S. The outcome of drug smuggling by 'body-packers' - the British experience. Ann R Coll Surg Engl 2002; 84:358.

6. Mandava N, Chang RS, Wang JH. Establishment of a definitive protocol for the diagnosis and management of body packers (drug mules). Emerg Med J 2011;28:98e101. doi:10.1136/emj.2008.059717.

7. Wong GCK, Lai KK, Chung CH. Management of body packers in the emergency department. Hong Kong J. Emerg. Med. 2005;12(2):112-

8. De Bakker JK, Nanayakkara PWB, Geeraedts Jr LMG, et all. Body packers: a plea for conservative treatment. Langenbecks Arch Surg. 2012;397:125-130.

9. Glass J and Scott H. Surgical Mules: The smuggling of drugs in the gastrointestinal tract. J. R. Soc. Med. 1995; 88:450-453.

10. Bogusz, M J et al. Internally concealed cocaine: Analytical and diagnostic aspects. J. Forensic Sci. 1995; 40:811-815.

11. McCarron MM, Wood JD. The cocaine 'body packer' syndrome: diagnosis and treatment. JAMA 1983; 250:1417-20.

12. Ab Hamid S, Abd Rashid SN, Saini SM. Characteristic imaging features of body packers: a pictorial essay. Jpn J Radiol. 2012;30:386-392. DOI 10.1007/s11604-012-0069-4.

13. Karhunen, $\mathrm{P}$ et al. Pitfalls in the diagnosis of drugs smugglers abdomen. J. Forensic Sci. 1991; 36:397-402.

14. Rousset P, Chaillot PF, Audureau E, et al. Detection of residual packets in cocaine body packers: low accuracy of abdominal radiographya prospective study. Eur Radiol (2013) 23:2146-2155. DOI 10.1007/s00330-013-2798-x

15. Flach PM, Ross SG, Ampanozi G, et all. "Drug mules" as a radiological challenge: Sensitivity and specificity in identifying internal cocaine in body packers, body pushers and body stuffers by computed tomography, plain radiography and Lodox. European Journal of Radiology. 2012;81:2518-2526.

16. Schmidt S, et al. Detection of ingested cocaine-filled packets diagnostic value of unenhanced CT. Eur J Radiol. 2008; 67(1):133-8.

17. K. Lee, Koehn M, Rastegar RF, et al. Body Packers: The Ins and Outs of Imaging. Canadian Association of Radiologists Journal. 2012(63):318-322.

18. Pidoto RR, et al. A new method of packaging cocaine for international traffic and implications for the management of cocaine body packers. J Emerg Med. 2002; 23:149-153

19. Ziegelera E, Grimma JM, Wirtha S, et al. Computed tomography scout views vs. conventional radiography in body-packers - Delineation of body-packs and radiation dose in a porcine model. European Journal of Radiology 2012; 81:3883-3889.

20. Hergan K, Kofler K, Oser W. Drug smuggling by body packing: what radiologists should know about it. Eur Radiol, 2004 ; $14:$ 736-742.

21. Sohail S. CT scan of body packers: findings and costs J Pak Med Assoc. 2007; 57: 400-403.

22. Beckley I, Ansari NAA, Khwaja HA, et al. Clinical management of cocaine body packers: the Hillingdon experience. J Can Chir. 2009;52(5):417-421.

23. Wackerle B. et al. Detection of narcotic-containing packages in "body-packers" using imaging procedures. Studies in vitro and in vivo. Rofo. 1986;145:274-277. 